\title{
Preparation and Properties of Papain Precipitated from Fresh Latex of Papaya Fruits (Carica papaya)
}

\author{
Esmat, M. El-Zalaki \\ Food Science and Technology Dept., Fac. of Agric., Alexandria Univ. El-Statby 21545, Alexandria, \\ Egypt.
}

Received: 26 January, 2021

Revised: 22 February, 2021

Accepted: 4 May, 2021

\begin{abstract}
Papain was precipitated from cysteine hydrochloride extract of fresh latex of papaya fruits planted in Alexandria Governorate, Egypt. Three precipitants; namely, ethyl alcohol, acetone and sodium chloride resulted in proteolytic activity recovery 84.8 (of three fractions), 85.2 and $76.7 \%$, respectively. Acetone was found to be the most promising rapid and simple conditions for preparing acetone dry powder of partially purified crude papain. Papain properties indicated that the maximum activity was attained at $\mathrm{pH} 7.5-8.0$, and temperature of $75-85^{\circ} \mathrm{C}$. The activity was not affected by $\mathrm{Na}^{+}$or $\mathrm{Ca}^{++}$ions. Various degrees of inhibition were exerted by $\mathrm{Ni}^{+,+}, \mathrm{Co}^{++}, \mathrm{Pb}^{++}$, and $\mathrm{Hg}^{++}$, while $\mathrm{Cu}^{++}$, caused complete inhibition .On the other hand, the proteolytic activity increased to various levels, in the presence of $\mathrm{Sn}^{++}$, cyanide, thioglycolic acid, and cysteine hydrochloride. The catalytic activation (49\%) of $\mathrm{Sn}^{++}$was found to depend to some extent on the concentration. A mixed stored papain-oryzae protease preparation, was found to retain 71,63 , and $54 \%$ of its proteolytic activity upon storage at $25^{\circ} \mathrm{C}$ for 1,2 ,and 3 months ,respectively. The retained activity was more pronounced, being 92,80 , and $69 \%$, respectively upon storage at $-5^{\circ} \mathrm{C}$ for the aformentioned durations, accordingly, storage at $-5^{\circ} \mathrm{C}$ for up to 2 months, was recommended. The storage stability of papain powder and solutions were studied. A papain-oryzae protease preparation was formulated for further use in meat tenderization.
\end{abstract}

Keywords: Papain preparation, properties, oryzae protease, storage stability

\section{INTRODUCTION}

The fresh papaya latex, is present in large latex vessels just under the skin of the fully green fruits of papaya (pawpaw) Carica papaya tree, the exudate was gathered while the fruits were still on the tree. Papain is present in the leaves, roots, green fruits, and is a predominant enzyme in papaya latex. Kimmel \& Smith (1957 and 1958) used commercial dried papaya latex for crystalline papain preparation, which catalyzes the hydrolysis of proteins. Various simple and spectrophotomete ric methods are reported to assess the proteolytic activity of various papain preparations, for comparison with pure papain for quality standardization, (Hashemi, 2008).Fresh latex can't stay well and should be dried to below 5\% moisture .Sun drying of the latex on trays though simple and common, resulted in least quality brown papain with considerable loss of enzyme activity. Oven drying at 35$40^{\circ} \mathrm{C}$ for $4-5 \mathrm{~h}$ is used in Sri Lanka, till a crumbly not sticky texture, Hashemi (2008). Up to the mid 1950s, papain from Sri Lanka dominated the market in three grades; fine white powder, white ovendried crumb, and dark sun-dried crumb. Up to the 1970s there were two grades; first or high grade oven-dried papain in powder or crumb form usually creamy white in colour, second or low grade sun dried brown papain in crumb form. Since 1970 as a result of new processing techniques papain has been re-classified into three groups: 1- crude papain - ranging from first grade white down to second grade brown. 2- crude papain in flake or powder form - sometimes referred to as semi-refined. 3spray dried crude papain -in powder form, referred to as refined papain, according to (Hashemi, 2008).

Papaya latex, solar dried at $40^{\circ} \mathrm{C}$ for $14 \mathrm{hr}$, contained $57 \%$ protein , $17 \%$ moisture, and papain represented the major proteolytic activity as found by Jeana et al. (2013). The solubility and dispersion of the enzyme as a protein in aqueous solution, is due to protein hydration. Reduction of protein hydration, when carried out at low temperature by the addition of organic solvents, as ethanol, methanol, and acetone, leads to protein precipitation, with preserving their biological functions, (Bioquochem. com, 2019). Also, the addition of salts as zinc sulphate, and ammonium sulphate to protein aqueous solution, restricted the available 
water, causing protein aggregation and precipitation, with keeping their biological function (Bioquochem. com 2019).

Plantations of papaya trees are needed for various economical values. The edible fruits are ripe after 2- 3 months. Green fruits are the main source for collection of papaya latex, for production of papain ,pectin , and other biologically active components . The skin of the green ripe papaya fruits contain about $10 \%$ pectin on dry weight basis, which can also be extracted. Crude papain has great use in food industry. The principal producers of crude papain are Zaire, Tanzania, Uganda and Sri Lanka. Most of the spray-dried papain comes from Zaire. The principal importing countries are the United States, Japan, United Kingdom, Belgium and France, (Hashmi, 2008). Spray dried papain has a high proteolytic activity and is totally soluble in water, but extreme care must be considered upon handling, because it can cause allergies and emphysema if inhaled. For this reason, spray dried papain is often encapsulated. Papain can trigger allergic reactions in susceptible individuals. Skin reactions may occur following contact with fresh latex from papaya; hypersensitivity reactions may be especially pronounced in persons allergic to latex (Kara Rogers, 2021).Papain, is used extensively in food processing. The main important use of papain in the meat industry is for meat tenderization and for the production of meat tenderizers, (Pradeep et al., 2019). Drying conditions play an important role on papain grade and quality. The main target of the present work aimed to avoid drying, and precipitate crude papain directly from the fresh papaya latex by safe, simple, rapid, and relatively inexpensive method.A storage stability of a mixture of papain - oryzae protease was investigated for further use on both of small or domestic scale, as meat tenderizer.

\section{MATERIALS AND METHODS}

Gathering papaya latex: The latex of papaya (Carica papaya) fruits, Known also as pawpaw, was gathered from the fully green fruits of papaya tree. Several longitudinal scratches were carried out on the surface of the fruits, while still hanged on the tree. The dropped exudate was gathered from the scratched green fruits .

Extraction of latex : The freshly gathered latex was extracted with $0.01 \mathrm{M}$ cysteine hydro- chloride solution, in proportion of $50 \mathrm{~g} / 100 \mathrm{ml}$, by mechanical stirring for $1 \mathrm{hr}$, followed by centrifugation at $6000 \mathrm{xg}$ for $10 \mathrm{~min}$. The clear supernatant was separated and kept at $5^{\circ} \mathrm{C}$, while the residue was four times extracted, each with $50 \mathrm{ml}$ of the aforementioned solution. The latex extracts were combined for papain precipitation.

Precipitation of papain: Three precipitants; namely, chilled ethyl alcohol, chilled acetone and sodium chloride were tried to select the most promising conditions for papain precipitation. Chilled ethanol $\left(-15^{\circ} \mathrm{C}\right)$ was successively added to the latex extracts that was cooled to $2^{\circ} \mathrm{C}$. to three concentrations of 50, 67 and $80 \%$, kept overnight at $-15^{\circ} \mathrm{C}$, then centrifuged at $3500 \mathrm{xg}$ for $10 \mathrm{~min}$, to collect each fractionated precipitate. Two acetone concentrations of 50 and $67 \%$ were used, for fractionation. Sodium chloride at a concentrations of 10 and $20 \%$, was also tried for papain precipitation. No precipitate appeared with $10 \%$, yet at the higher concentration of $20 \%$, white precipitate appeared after keeping the solution at $-5^{\circ} \mathrm{C}$. for 3 days.

Proteolytic activity: The proteolytic activity of crude papain and oryzae protease as enzyme units, was measured by Anson's method according to Greenberg (1955), McDonald \& Chen (1965), and Petrova \& Vintsyunaite (1966). Where, one enzyme unit being the amount of enzyme that produces in one minute, at $\mathrm{pH} 7.5$ and a temperature of $35^{\circ} \mathrm{C}$, products of hydrolysis containing one micro equivalent of tyrosine not perceptible with trichloroacetic acid. Oryzae protease was prepared as reported by El-Zalaki et.al. (1974).

Properties of papain: Effect of $\mathrm{pH}$ on the proteolytic activity was determined in a series of citrate-phosphate, phosphate-phosphate, and glycinesodium hydroxide buffers in a range of $\mathrm{pH}$ from 5.1 to 9.9 . The reaction mixture consisted of 2.5 $\mathrm{ml}$ buffer, $2.5 \mathrm{ml}$ of $5 \%$ aqueous casein solution, and $1 \mathrm{ml}$ of aqueous enzyme solution. The effect of temperature was carried out in a temperature range of 35 to $100^{\circ} \mathrm{C}$.

The effect of seven inorganic salts in the form of $\mathrm{SnCl}_{2} \cdot 2 \mathrm{H}_{2} \mathrm{O}, \mathrm{Pb}\left(\mathrm{Ch}_{3}, \mathrm{COO}^{-}\right)_{2} \cdot 3 \mathrm{H}_{2} \mathrm{O}, \mathrm{NaCl}, \mathrm{CaCl}_{2}$, $\mathrm{Ni} \mathrm{Cl}_{2}, 6 \mathrm{H}_{2} \mathrm{O}, \mathrm{Co} \mathrm{Cl}_{2} \cdot 6 \mathrm{H}_{2} \mathrm{O}, \mathrm{Hg} \mathrm{Cl}_{2}$, and $\mathrm{CuSO}_{4}$, as well as the effect of $\mathrm{KCN}$, cysteine hydrochloride, and thioglycolic acid on the proteolytic activity was studied, according to the method applied by Hurley \& Gardner (1963), with slight modifications. The activity was determined at the maximum $\mathrm{pH}$ of the 
enzyme using $1 \mathrm{ml}$ of $0.01 \mathrm{M}$ of a buffered tested compound with $4.0 \mathrm{ml}$ of buffered casein solution. The concentration of the tested ions and compounds in the reaction mixture was $1.6 \times 10^{-3} \mathrm{M}$, for comparing the percentage of activation or inhibition.

Stability of papain- oryzae protease preparation: Papain preparations may be supplied in a powder form or as liquid. The proteolytic activity of a combined papain- oryzae proteases preparation (10:1 w/w) was measured monthly, through storage at temperature of $25^{\circ} \mathrm{C}$ and $-5^{\circ} \mathrm{C}$, for 3 months. The stability of an enzyme mixture solution of $1 \%$ concentration in liquid form, was also assessed upon storage at a temperature of $5^{\circ} \mathrm{C}$. Five various solutions ; namely, aqueous, $14 \%$ sodium chloride, acetate buffer ( $\mathrm{pH} 4)$, phosphate buffer ( $\mathrm{pH} 7)$, and carbonate buffer ( $\mathrm{pH}$ 10) were used. The buffer solution was of concentration of $0.2 \mathrm{M}$.

\section{RESULTS AND DISCUSSION}

Papain extraction: The clear exudate fluid of the fresh papaya latex became opaque on exposure to air. The gathered latex was extracted with cysteine hydrochloride solution. The proteolytic activity of five successive extracts, were 9.9, 9.5, $7.3,5.1$, and 0.3 enzyme units/ml of the cysteine hydrochloride solution. The first four consecutive extracts were combined, while the fifth extract with negligible activity was discarded.

Precipitation of papain: The solubility of proteins can be lowered and precipitation can be induced by lowering the effective dielectric constant of the media. This is commonly achieved by adding a water-soluble solvent such as, ethanol or acetone to an aqueous solution of the enzyme solution, at low temperature to preserve the biological function of the protein (Bioquohem.com 2019). The results presented in (Table 1) show that the use of ethyl alcohol for papain precipitation from the combined latex extracts resulted in recovery of $84.8 \%$, of the enzyme units $(\mathrm{Eu} / \mathrm{ml})$ in three fractions. While on the other hand the use of acetone resulted in a recovery of $85.2 \%$ in two fractions. The method of Skelton (1968 ) using sodium chloride for precipitation was also tried, resulted in recovery of 76.7 $\%$. The method though direct and rapid, yet it was recommended for the preparation of small amounts of pure papain. Addition of some salts to protein aqueous solution, restricted the available water, causing protein aggregation and precipitation, with keeping their biological function, and the proteins can be re-dissolved (Bioquochem.com 2019).

According to the present results, precipitation of crude papain from the papaya latex cysteine hydrochloride extracted with acetone, as a simple and rapid method was carried out for further studies. That is because acetone is relatively inexpensive, available in a pure form, and acetone dry powder of crude papain was directly obtained after acetone decantation and evaporation.

Effect of $\mathrm{pH}$ and temperature on the proteolytic activity of papain: The results shown in Table (2) indicate that the papain preparation showed a maximum proteoltic activity in a $\mathrm{pH}$ range from 7.5 to 8.0 , being around $4.0 \mathrm{Eu} / \mathrm{ml}$ and at a tem-

Table 1: Recovery of proteolytic activity as enzyme unit $\mathrm{ml}(\mathrm{Eu} / \mathrm{ml})$ of papaya latex extract upon fractionation

\begin{tabular}{lcccc}
\hline \multicolumn{1}{c}{ Fractions } & EU/ml & Total EU & EU recovery $\%$ & EU/mgN \\
\hline $\begin{array}{l}\text { Initial extracts } \\
\text { Ethyl alcohol }\end{array}$ & 9.2 & 721 & 100 & 1.76 \\
$\quad 50 \%$ & 4.7 & 281 & & 1.68 \\
$\quad 67 \%$ & 6.8 & 272 & 39.0 & 1.43 \\
$\quad 75 \%$ & 2.9 & 58 & 37.7 & 4.33 \\
Total recovery & & & 8.1 & 1.74 \\
\hline Acetone & & & 84.8 & 3.20 \\
$\quad 50 \%$ & 5.6 & 456 & 63.2 & -- \\
$\quad 60 \%$ & 5.3 & 159 & 22.0 & 3.11 \\
Total recovery & & & & - \\
\hline Sodium chloride & 0.0 & 0.0 & 76.7 & \\
$10 \%$ & 9.7 & 680 & & \\
$20 \%$ & & & & \\
\hline
\end{tabular}


Table 2: Effect of $\mathrm{pH}$ and temperature $\left({ }^{\circ} \mathrm{C}\right)$ on the proteolytic activity $(\mathrm{Eu} / \mathrm{ml})$ of papain

\begin{tabular}{lccccccccccc}
\hline \multicolumn{1}{c}{$\mathbf{p H}$} & $\mathbf{5 . 1}$ & $\mathbf{5 . 5}$ & $\mathbf{6 . 0}$ & $\mathbf{6 . 5}$ & $\mathbf{7 . 2}$ & $\mathbf{7 . 5}$ & $\mathbf{8 . 0}$ & $\mathbf{8 . 5}$ & $\mathbf{9 . 1}$ & $\mathbf{9 . 4}$ & $\mathbf{9 . 9}$ \\
\hline $\mathrm{Eu} / \mathrm{ml}$ & 2.1 & 3.0 & 3.3 & 3.5 & 3.8 & 4.0 & 4.1 & 3.5 & 2.9 & 2.2 & 2.0 \\
$\mathrm{Temp}$. & 40 & 45 & 50 & 55 & 60 & 70 & 75 & 80 & 85 & 90 & 100 \\
$\mathrm{Eu} / \mathrm{ml}$ & 5.9 & 6.10 & 6.5. & 6.9. & 7.0 & 7.3 & 7.6 & 7.8 & 7.6 & 7.2 & 6.2 \\
\hline
\end{tabular}

perature range of $75-85^{\circ} \mathrm{C}$. Bekhit et al. (2014) reported that the optimum $\mathrm{pH}$ and temperature of papain proteolytic activity on meat was $7-8$, and $60-65^{\circ} \mathrm{C}$, and on casein 7.5 , and $37^{\circ} \mathrm{C}$, respectively. Accordingly, the present results confirmed that the prepared acetone dry powder of papain is a very promising component in meat tenderization, particularly in the early stages of cooking, where the proteolytic activity diminished by further boiling.

Effect of some compounds on the proteolytic activity of papain: The results presented in Table (3) indicate that the activity of papain was not affected by $\mathrm{Na}^{+}$or $\mathrm{Ca}^{++}$ions . The present result is different from that reported by Kaul et. al. (2002), indicating that the activity of papain increased to a maximum of $18 \%$ in presence of calcium ions at $1 \times 10^{-3} \mathrm{M}$ concentration. The ions of $\mathrm{Cu}^{++}$, caused complete inhibition, and various degrees of inhibition were exerted by $\mathrm{Ni}^{+,+}, \mathrm{Co}^{++}, \mathrm{Pb}^{++}$, and $\mathrm{Hg}^{++}$. According to Hashemi (2008), heavy metals as iron, cupper, or brass should not come in contact with papaya latex ,as it caused discolouration and loss of activity, plastic or stainless steel utilities are recommended.

Sluyteman (1967) found that papain is revers- ibly inactivated in the presence of air and low concentrations of cysteine. Inactivation was enhanced by $\mathrm{Fe}^{++}$and $\mathrm{Cu}^{++}$and is retarded by EDTA. In the absence of cysteine, papain is inactivated at a much lower rate in an almost irreversible manner.

Notwithstanding, the proteolytic activity increased to various levels in the presence of the other tested substances, particularly in the presence of $\mathrm{Sn}^{++}$ions. Cyanide, thioglycolic acid, and cysteine hydrochloride also increased papain activity. Sumner \& Myrback (1951) stated that the activity of the enzyme depends on the presence of reversibly oxidizable and reducible sulfhydryl groups. Skelton $(1968 \mathrm{~b} \& \mathrm{c})$ demonstrated that crude extracts of papaya latex were activated by reducing agents such as cyanide, hydrogen sulfide, cysteine and glutathione, and inactivated by oxidizing agents. According to this property, papain is known as a cysteine protease .

Further study was carried out to investigate the effect of $\mathrm{Sn}^{++}$concentration $\left(0.5 \times 10^{-4}\right.$ to $2.0 \times 10^{-4}$ M) on the proteolytic activity of papain. The results in Table (4) indicate that the percentage of activity increased up to a concentration of $1.0 \times 10^{-4} \mathrm{M}$ of $\mathrm{Sn}^{++}$, no activation was thereafter demonstrated.

Table 3: Effect of some inorganic ions and organic compounds on the proteolytic activity of papain (EU/ ml)

\begin{tabular}{lccc}
\hline \multicolumn{1}{c}{ Tested ions } & Proteolytic activity & Activation\% & Inhibition \% \\
\hline Control & 3.5 & - & - \\
$\mathrm{Na}+$ & .35 & - & - \\
$\mathrm{Ca}++$ & .35 & - & - \\
$\mathrm{Cu}++$ & 0.0 & - & 100 \\
$\mathrm{Ni}++$ & 0.5 & - & 85 \\
$\mathrm{Co}++$ & 2.2 & - & 38 \\
$\mathrm{~Pb}++$ & 2.5 & - & 30 \\
$\mathrm{Hg}++$ & 3.1 & - & 12 \\
$\mathrm{Sn}++$ & 49 & - \\
$\mathrm{CN}-$ & 5.3 & 39 & - \\
Thioglycolic acid & 4.9 & 27 & - \\
Cystein-HCL & 4.5 & 16 & - \\
\hline
\end{tabular}


Table 4: Effect of $\mathrm{Sn}^{++}$concentration on the proteolytic activity $(\mathrm{EU} / \mathrm{ml})$ of papain.

\begin{tabular}{lccccccc}
\hline Concentration* $^{*}$ & 0.0 & 0.5 & 1.0 & 2.0 & 4.0 & 8.0 & 16.0 \\
\hline EU/ml & 3.5 & 4.1 & 5.6 & 5.5 & 5.3 & 5.3 & 5.3 \\
Activation\% & 0.0 & 41.8 & 58.2 & 54.8 & 49 & 49 & 49
\end{tabular}

* $\mathrm{Sn}++$ in the reaction mixture M x 10-4.

According to the present results, this effect on a catalytic reaction is depending to some extent on the concentration, such a finding deserves further study.

Stability of papain-oryzae protease preparation : The results of the present investigation, showed that the stored papain-oryzae protease that prepared, retained 71,63 , and $54 \%$ of its proteolytic activity upon storage at $25^{\circ} \mathrm{C}$ for a duration of 1,2 , and 3 months ,respectively. On the other hand the retained activity was more pronounced, being 92,80 ,and $69 \%$, respectively upon storage at $-5^{\circ} \mathrm{C}$ for the same duration. Accordingly, storage at $-5^{\circ} \mathrm{C}$ for up to 2 months, was recommended. Commercial crude papain was found to be variable in composition and unstable during storage, these data are in accordance with Schwartz Laboratories (1959).

The results presented in Table (5) show that the retained activity of the papain-oryzae protease solutions, stored at $5^{\circ} \mathrm{C}$, diminished by further storage up to 36 days. The least retained activity was demonstrated in the aqueous solution, while generally the highest activity was that reported in that of $14 \%$ sodium chloride solution. The stability differed with the $\mathrm{pH}$ and the duration of storage as shown in Table (5). Acetate buffer ( $\mathrm{pH} 4)$, exhibited better stability than phosphate buffer ( $\mathrm{pH} \mathrm{10)}$, which markedly decreased the retained activity . This effect can be related to the difference, in the $\mathrm{pH}$ and the ionic strength of the solutions, according to Fox \& Foster (1957).

Table 5: Retained proteolytic activity of $1 \%$ papainoryzae protease solutions, stored at $5^{\circ} \mathrm{C}$

\begin{tabular}{lccc}
\hline \multirow{2}{*}{\multicolumn{1}{c}{ Solutions }} & \multicolumn{3}{c}{ Days of storage } \\
\cline { 2 - 4 } & 12 & 24 & 36 \\
\hline Aqueous & 48 & 11 & 0 \\
14\% sodium chloride & 80 & 69 & 59 \\
Acetate buffer (pH 4) & 71 & 66 & 52 \\
Phosphate buffer (pH 7) & 11 & 3 & 0 \\
Carbonate buffer (pH 10) & 57 & 46 & 36 \\
\hline
\end{tabular}

\section{ACKNOWLEDGEMENTS}

Great appreciation and thanks are due to the valuable efforts of everyone who shared in the represented study.

\section{REFERENCES}

Bekhit, A. A., Hopkins, D. L., Geesink, G., Bekhit, A. A., \& Franks, P. 2014. Exogenous proteases for meat tenderization. Critical Reviews in Food Science and Nutrition, 54: 1012 - 1031.

Bioquochem.com. 2019 . Principals of various protein precipitation methods. $12 / 9$.

El-Zalaki, E. M., Mohasseb, Z.S \& Mohamed, M. S. 1974. Microbial proteases for meat tenderization. Two partially purified proteases of Aspergillus oryzae and their properties. Alexandria Journal of Agriculture Research, 22: $63-71$.

Fox, S.W \& Foster ,J. F. 1957. Introduction to Protein Chemistry. John Wiley \& Sons Inc. pp $241-245$.

Greenberg, D.M. 1955. Plant Proteolytic Enzymes. Methods in Enzymology, 2, Academic Press Inc. New York. pp $54-64$.

Hashimi, F. 2008. Papain Production (Practical Action Brief). www.appropedia.org

Hurley, W. C. \& Gardener, E. A. 1963.Some characteristics of proteolytic enzyme system of Pseudomonas fluorescens. Journal of Food Science, 28: $47-54$.

Jeana S. M., Helen J. V., Renato D. B., Jessie G. G. \& Elnor C. Roa . 2013. Chemical Analysis of Carica papaya L. Crude Latex .American Journal of Plant Sciences, 4:1941-1948.

Kara, R. 2021. Senior Editor, Science / Papain / Recent Revise. Britannica.com.

Kaul, P., Sathish, H.A. \& Prakash,V . 2002.Effect of metal ions on structure and activity of papain from Carica papaya. Nahrung. 46: $2-6$.

Kimmel, J. R. \& Smith,E.L. 1957. The Properties of Papain. Advances in Enzymol. Interscience Pub.Inc. New York, 19: 268-334.

Kimmel,J. R\& Smith,E.L.1958. Crystalline Papain and Benzoyl-L-arginineamide. Biochemical Preparations .John Wiley \& Sons Inc. ,New York. 6: 61- 67. 
Mc Donald, C.E. \& Chen, L.A. 1965. The Lowry modification of the Folin reagent for determination of proteinase activity. Analytically of Biochemistry. 10: 175- 177 .

Petrova, I.S. \& Vintsyunaite, M. M.1966. Determination of proteolytic activity of enzyme preparates of microbiological origin .Prikl. Biochemical Microbiological, 2: 322 - 327.

Pradeep, K.S.,Neeraj,S. \& Ojha, B.K. 2019. Enzymes in the Meat Industry. In: Enzymes in Food Biotechnology. Production, Application, and Future Prospects. Kuddus, M. (Ed), Academic Press. pp 111- 128.

Schwartz Laboratories. 1959.Purification of Papain . Patent Brit. 808, 300, Feb.4.
Skelton, G.S. 1968a. Column chromatography of papaya proteinase on hydroxyapatite. Journal of Chromatography. 35:283- 6.

Skelton, G.S. 1968b. Papaya proteinases. II Effect of ascorbic acid on proteolytic activity. Enzymologia 35 : 275-8.

Skelton, G.S. 1968c. Papaya proteinases. III Effect of activators on the hydrolysis of benzol argininiemide. Enzymologia 35 : 279-82

Sluyteman, A.E. 1967. The activation reaction of papain. Biochimica et Biophysica Acta (BBA) - Enzymology. 139: 430-438.

Sumner, B. \& Myrback, K. 1951. The Enzymes Theory and Mechanism of Action. Academic Press Inc. New York, pp 853- 57.

\section{تحضير وصفات الهستحضر الهترسب لإنزيم البابيين من الالكس الطازج

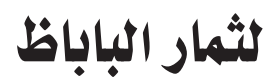

عصمت الزبلاقى

قسم علوم و تقتية الأغذية ، كلية الزراعة جامعة الاسكندرية ، شارع أفلاطون ، الشاطبى .

Carica pa- استهدفت هذه الدراسة ترسيب مستحضر بابيين من اللاتكس المتحصل عليه من ثمار الباباظ paya

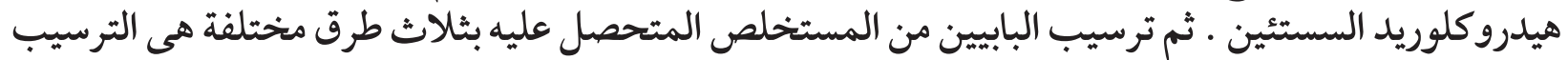

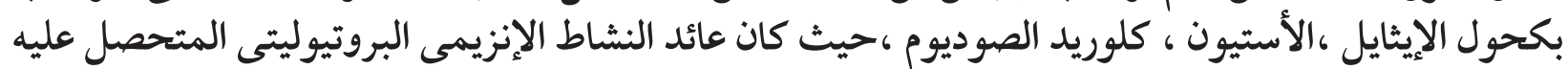

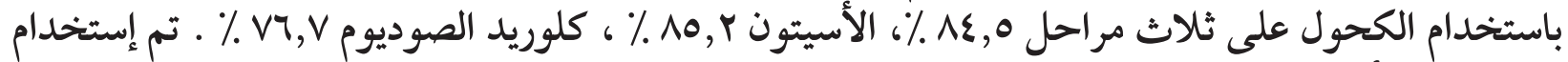

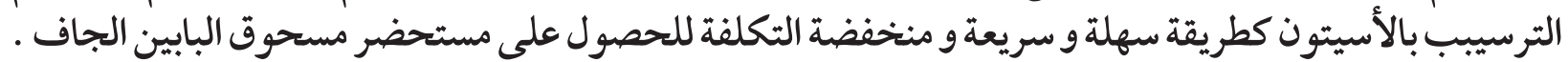

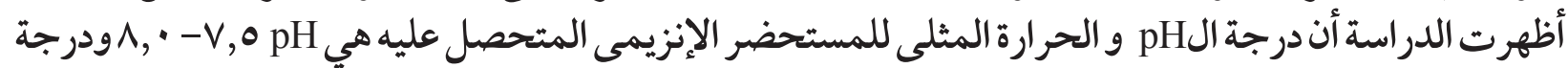

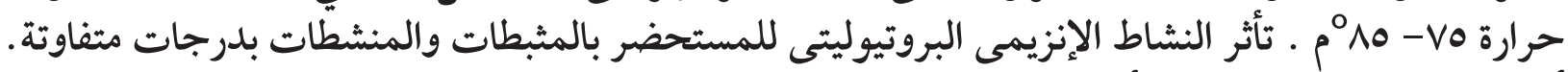

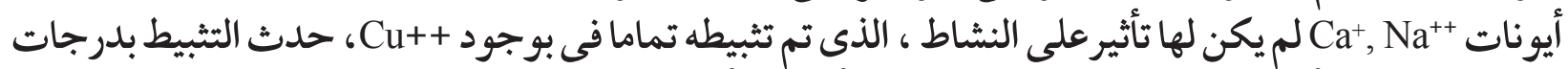

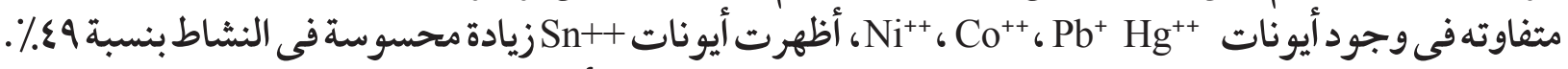

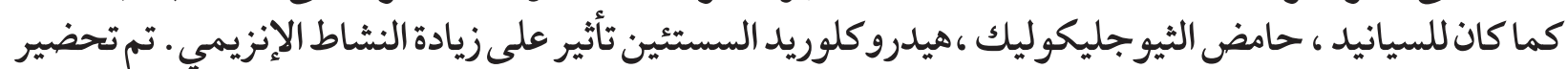

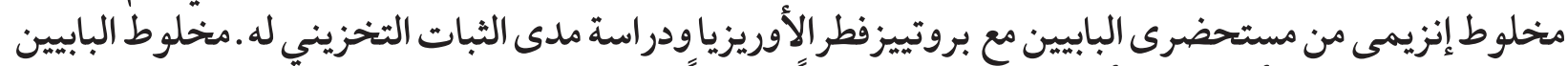

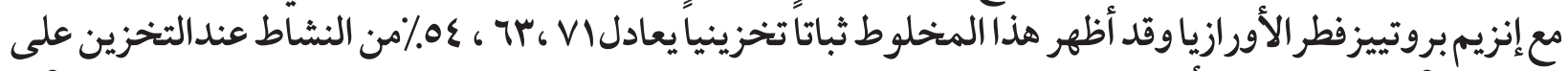

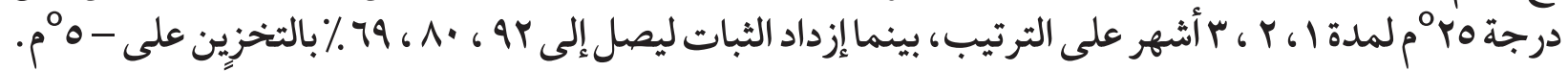

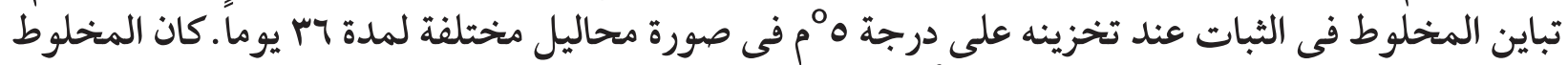

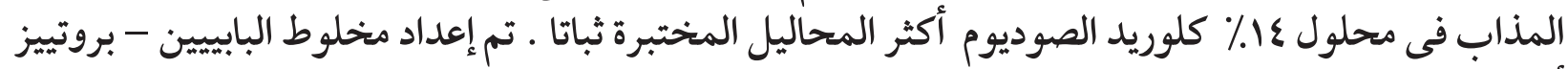

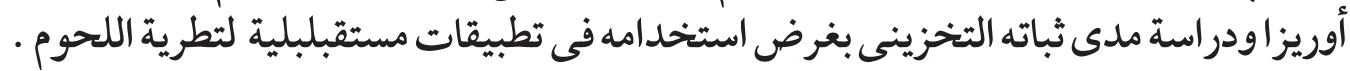

